Economic review

\section{September 2010}

\author{
Graeme Chamberlin
}

\section{Office for National Statistics}

\section{SUMMARY}

Gross Domestic Product rose by 1.2 per cent in the second quarter due to strong rebound in construction output from the weather-affected level in the first quarter, and a pick up in services sector growth. This is despite the negative impacts of the volcanic ash cloud and industrial action in the air transport sector. On the demand-side of the National Accounts, GDP growth was supported by a return to positive stockbuilding. Net trade though made a negligible contribution to growth, suggesting that sterling depreciation has not yet had a positive effect. In the labour market, employment rose in the second quarter of the year, but remains below pre-recession levels and rates. There is evidence of a strong rise in parttime employment through the recession, with self-employment also strengthening during 2009. Recent output increases have been partly delivered through higher labour productivity. Producer prices inflation continues to be driven by the recent trend in oil prices, even the services producer price index through the impact on freight transport.

\section{Construction leads the pick up in second quarter growth}

atest data show that the UK economy grew by 1.2 per cent in the second quarter of the year, a slight upward revision of 0.1 percentage point from the first estimate published last month. The chain volume measure of Gross Domestic Product (GDP) has now grown for three successive quarters, with the latest quarter of growth being a marked pick up on the growth of 0.3 per cent recorded in the first quarter (Figure 1). However, the level of output still remains significantly below its pre-recession peak in 2008 Q1. Between 2008 Q1 and 2009 Q3, GDP fell by a total of 6.4 per cent. Despite the recent recovery, GDP still remains 4.5 per cent below its level in 2008 Q1.

The latest quarter of rapid growth was driven by the services and construction sectors (Figure 2). Total output of the services industries grew by 0.7 per cent

\section{Figure 1}

\section{Gross Domestic Product}

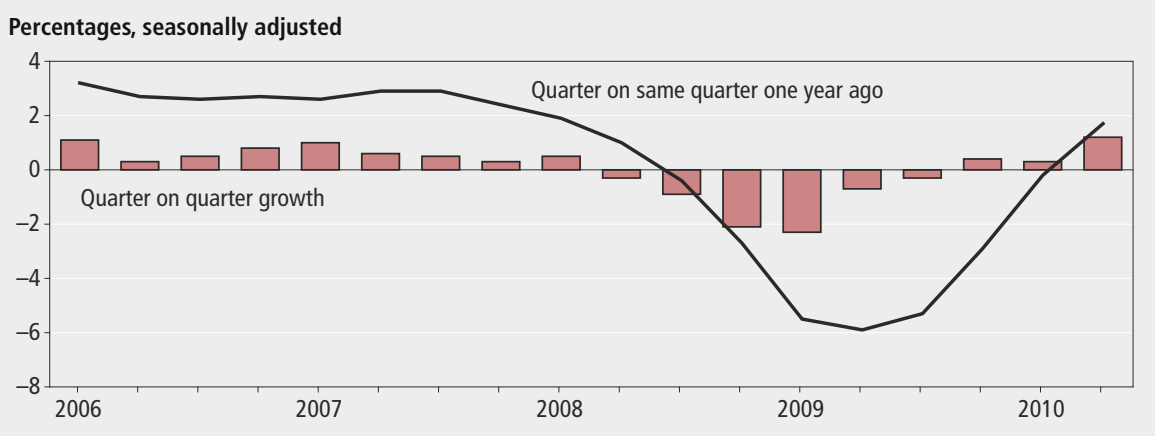

Source: GDP Output, Income and Expenditure in the second quarter, although as Figure 2 shows, growth was not uniform across all sub-sectors with the transport and communications sector recording a 2.2 per cent fall in output. Whilst it is unsurprising that the services sector, which accounts for around three-quarters of total valuedadded in the UK, made an important contribution to second quarter growth, the contribution of the construction sector stood out. Like services, this contributed around 0.5 percentage points to growth in the quarter, but only accounts for around 6 per cent of total output based on 2006 weights. Its significant contribution resulted from very rapid growth of 8.5 per cent over the quarter.

\section{Production output rises for the third successive quarter}

igure 3a shows the contributions to

- total output growth in the production

industries by main category of output.

Clearly production output fell abruptly during the recession, driven in particular by the capital goods and intermediate goods producing industries. This reflects the strong fall in investment (and increased rates of de-stocking) as firms reduced capacity in line with falling demand and the uncertain economic outlook.

As the global economy begins to recover these trends would be expected to reverse. Total production has grown for three successive quarters since reaching a trough in 2009 Q3, expanding by a further 1.0 per cent in the second quarter of this year. Output in the capital goods producing industries grew by 2.0 per cent and output of the intermediate goods producing industries by 0.8 per cent, with both contributing around 0.4 percentage points to total production growth in 2010 Q2. In recent quarters the rate at which firms have been running down their inventories has slowed. Production output, which tends to be highly traded relative to services output, has also benefited from the improving global economy which has resulted in growing UK exports.

Production of consumer goods is a fairly small part of the UK economy. Durables and non-durables together 


\section{Figure 2}

\section{Contributions to GDP growth by industry, ${ }^{1} 2010$ Q2}

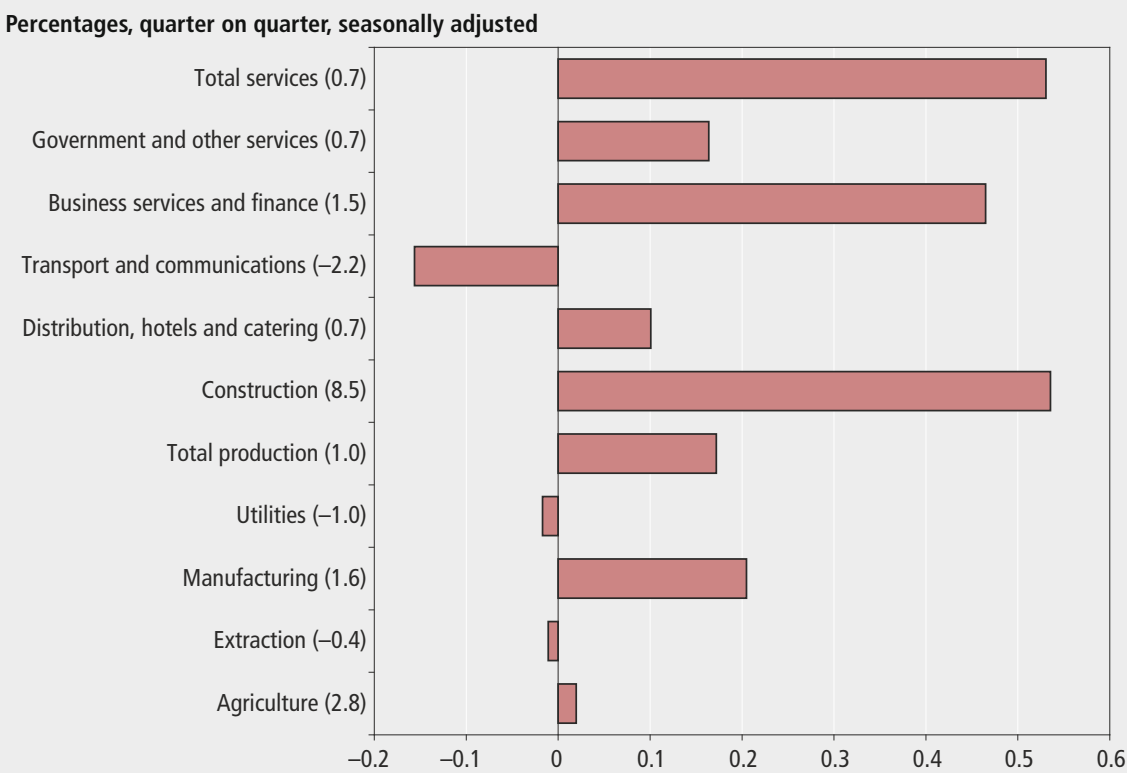

Notes:

Source: GDP Output, Income and Expenditure

1 Quarter on quarter change in output by industry shown in brackets

\section{Figure 3a \\ Contributions to growth in the production industries by category of output}

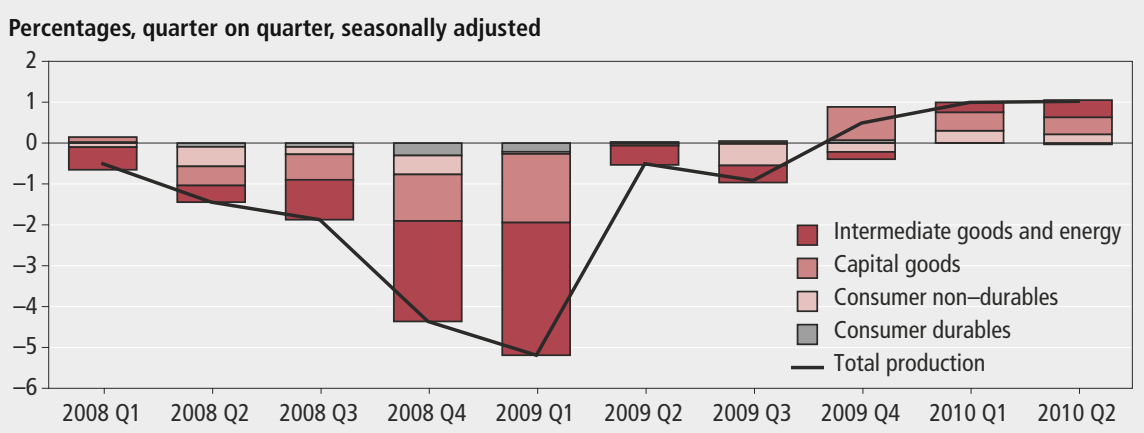

Source: Index of Production

\section{Figure $3 b$}

\section{Contributions to growth in the production industries by industry}

Percentages, quarter on quarter, seasonally adjusted

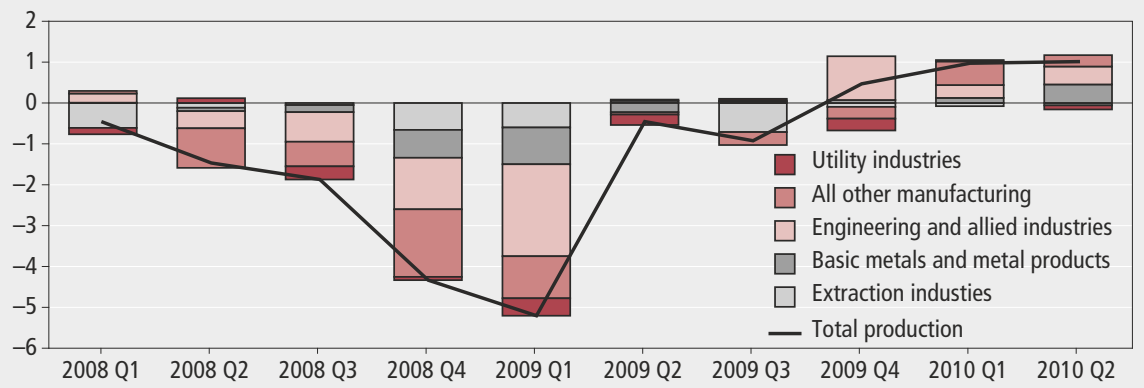

Source: Index of Production

account for just over a quarter of total production output, which in itself accounts for less than 20 per cent of GDP. This is reflected by their relatively small contributions to production sector growth as shown in Figure 3a.
Figure $\mathbf{3 b}$ complements Figure $3 \mathbf{a}$ by showing the contributions to growth made by the main production industries. The engineering and allied industries primarily consist of capital goods producing industries, such as office equipment, machinery, transport equipment, scientific and optical apparatuses and so on, so it understandable why the contributions to growth in each quarter are similar to those of the capital goods producing industries in Figure 3a. In the latest quarter, output in these combined industries grew by 1.9 per cent contributing 0.4 percentage points to total output. Output in the other production industries largely represents those of the intermediate goods industries. For example the extraction industries largely reflect oil and gas output, the utilities industries reflect water, gas and electricity, and basic metals and metal products which tend to be an important input into other production and construction outputs. This final component of production sector output has also made an important contribution to the direction of growth in the last two years. In the latest quarter of published data, 2010 Q2, output grew strongly by 5.5 per cent contributing 0.5 percentage points to total production growth in the quarter.

\section{Construction output grows by 8.5 per cent in 2010 Q2}

I

here was marked growth in construction output in the second quarter of the year. As Figure 4 shows, the latest quarter of growth is in sharp contrast to the recent performance of the sector. While GDP as a whole has grown for three successive quarters since reaching a trough in the third quarter of 2009, until now the construction sector had not followed suit. Construction demand is likely to be particularly susceptible to uncertainty over the economic outlook and restrictions in the availability of credit. In fact, after contracting in both 2009 Q4 and 2010 Q1, construction output was in the first quarter of the year almost back at the level of the previous trough in 2009 Q2.

In the second quarter, the increase in output has been broad-based across the main categories of output. New work, which accounts for about three-fifths of total output expanded by 9.8 per cent in the quarter.

Within this, there were notable contributions form new (private) housing work which grew by 22.1 per cent and public new works which grew by 10.4 per cent.

Repair and maintenance work is also an important part of construction sector output, accounting for about two-fifths of the total. This too had fallen during 


\section{Figure 4}

\section{Contributions to growth in construction output}

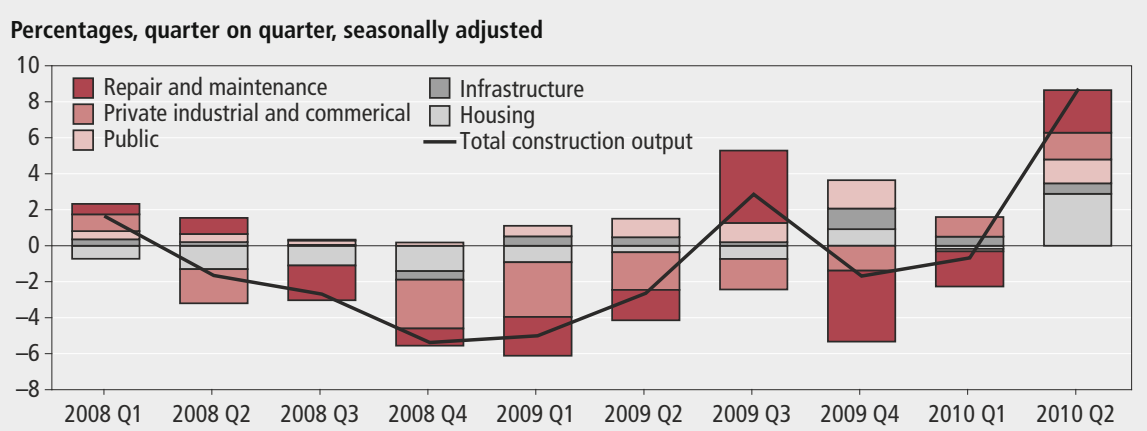

Source: Output in the construction industry

\section{Figure 5}

\section{Contributions to growth in services output}

Percentages, quarter on quarter, seasonally adjusted

Other
Private households with employed persons $(-1.4)$

Other service activities (1.2)

Recreational, cultural \& sporting activities $(-0.3)$

Activities of membership org nec $(-0.7)$

Sewage and refuge disposal (0.8)

Health and social work (1.5)

Education (1.2)

Public admin and defence $(-0.5)$

Other business activities (1.9)

Computer and related activities (1.5)

Renting of machnery and equipment (1.3)

Real estate \& letting of dwellings (1.2)

Financial intermediation (1.5)

Post and telecommunications (0.7)

Supporting and auxiliary transport (-3.6)

Air transport (-11.5)

Land transport (-2.7)

Hotels and restaurants (1.6)

Retail (1.3)

Wholesale (0.0)

Motor trades (-1.2)

$$
-0.10
$$

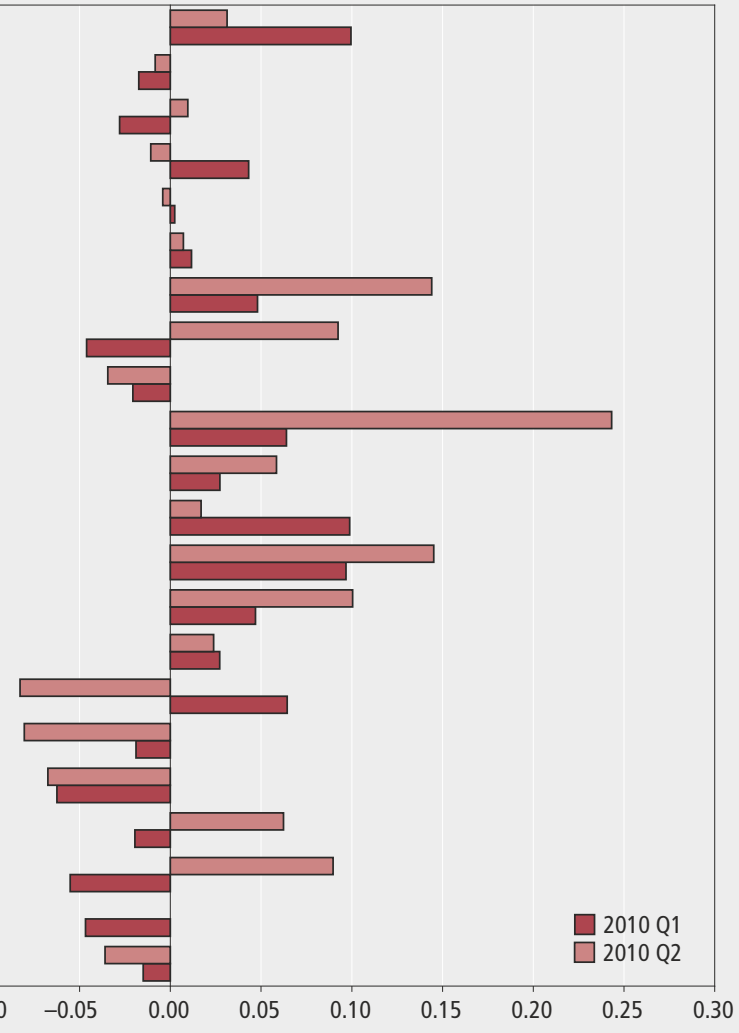

\section{Notes:}

12010 Q2 quarter on quarter growth rate for each industry in brackets

the downturn, particularly the non-

housing component. In 2010 Q2 output

recovered by 6.6 per cent, contributing 2.4

percentage points to growth.

The nature of construction output, which tends to be lumpy, means that large quarter on quarter movements are not uncommon. However, growth of 8.5 per cent in one quarter is towards the upper end of what has been experienced in the past, and much stronger than recent tepid activity. There are a number of possible factors that might explain this strong second quarter rebound. In particular, bad weather in January may have depressed output in the first quarter

Source: Index of Services

- therefore making second quarter output appear much stronger in comparison. Monthly figures (not seasonally adjusted) show that construction output in January was some 20 per cent lower than the monthly average in 2009 Q4. A related point is that, despite very strong growth in the second quarter, the level of output is still considerably below previous peaks, and up until now construction output had been lagging behind that in the production and services sectors of the economy and GDP overall - all of which returned to growth by the end of 2009 . Therefore strong growth has been from a relatively low base. Second, new orders in the construction industry began to pick up towards the end of 2009, which until now have not been reflected in the output figures. These would be expected to eventually emerge in new work output, the main driver of second quarter growth. However, new orders fell back sharply in 2010 Q2.

\section{Growth in business services and finance continues}

igure 2 presented the contributions
to GDP growth made by the main
categories of services output in

the second quarter of the year. Figure $\mathbf{5}$, using the Index of Services, shows the contributions of individual services industries to growth in the last two quarters in greater detail.

Overall service sector growth accelerated from 0.3 per cent in Q1 2010 to 0.7 per cent in Q2 2010. Weaker growth in the first quarter of the year (noting that service sector output also grew by 0.7 per cent in Q4 2009) partly reflected the bad weather in January, where heavy snowfall appeared to have some negative impact on those industries where footfall and transport are important. The motor trades, wholesale, retail, hotels and restaurants and land transport industries reduced services growth by 0.2 percentage points over the quarter. The reversion in the rate of VAT from 15 per cent to 17.5 per cent may also have led to some consumption being brought forward to the final quarter of 2009, again impacting negatively on the output of these industries during the first quarter. With these in mind, stronger second quarter growth, especially in the retail and hotels and restaurants industries, may partly represent a rebound from the contraction in the first quarter.

The largest negative contributions to growth in the second quarter were from the land transport, air transport and auxiliary transport services divisions. Together they reduced total service sector growth by around 0.2 percentage points. Air transport, in particular, contracted sharply over the quarter, down by 11.5 per cent due to the effects of the Ash cloud and BA cabin crew strikes. In April 2010, a single month fall in output of 15.4 per cent was recorded. This clearly had a knock-on impact on supporting and auxiliary transport services.

Various parts of the services sector have shown robust growth through the first half the year. The important business services and finance sector, which accounts for around 40 per cent of total services output, and just over 
30 per cent of GDP, grew by 1.5 per cent in the second quarter, continuing the momentum from the first quarter when the sector grew by 1.0 per cent. Data from the Index of Services further disaggregates the performance of the sector. This shows that growth was broad-based as each industry grew in excess of 1.0 per cent over the quarter. Financial intermediation output grew by 1.5 per cent, letting of dwellings and real estate activities by 1.2 per cent, renting of machinery and equipment by 1.3 per cent, computer and related activities by 1.5 per cent, and other business services, which consists of a manifold of activities including legal services, accountancy, management consultancy, architecture among others by 1.9 per cent over the quarter. The stronger performance of these primarily business-to-business activities may suggest growing optimism in the corporate sector.

Growth in education and health output also improved in the second quarter compared to the first, recording growth of 1.2 per cent and 1.5 per cent respectively and together contributing around a quarter percentage point to total service sector growth. Both of these industries, especially health, have exhibited fairly robust growth through the recession, likely due to the high proportion of public sector delivery which tends to be more immune to cyclical swings. However, both education and health output fell in January, indicating that they may also have been adversely affected by the weather disruptions during that month.

\section{Total expenditure grows in quarter two as businesses start to restock}

\footnotetext{
- he GDP Output, Income and Expenditure release publishes the first estimates for the expenditure components of GDP for any quarter.
} Figure 6 shows the contributions of each of these to GDP growth in each of the last three published quarters.

Compared to the first quarter of the year, larger positive contributions to growth in the second quarter were made by household consumption, net trade, and most significantly the 'other' category. In contrast, government consumption and gross fixed capital formation made smaller contributions than before.

Household consumption contracted

\section{Figure 6}

\section{Contributions to GDP growth by main category of expenditure}

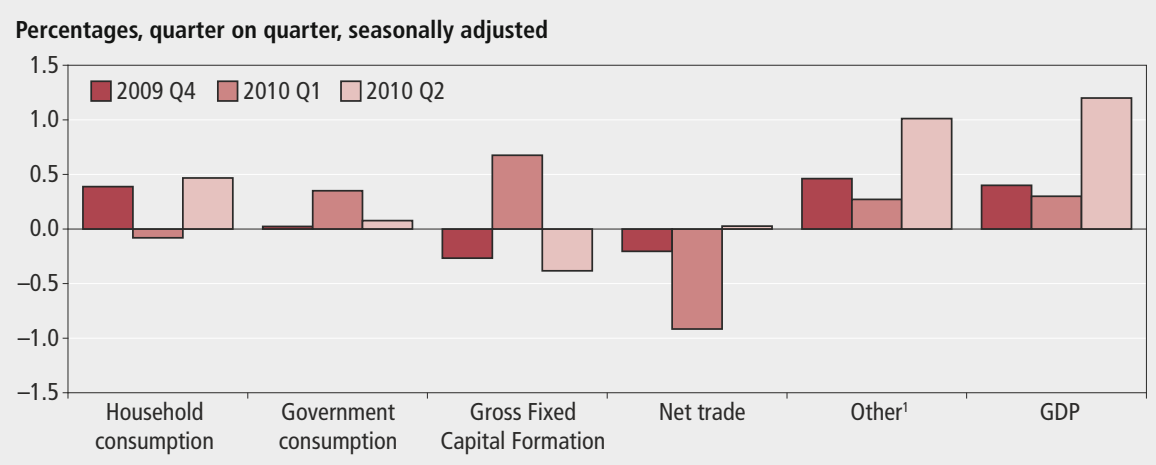

Notes:

Source: GDP, Output, Income and Expenditure

1 The 'Other' category consists of Non-profit institutions serving households (NPISH), valuables and inventories. Here it has been calculated as a residual.

in the first quarter of the year, before rebounding by 0.7 per cent in the second. As shown by output movements in some of the services industries over the same period, there is evidence that the reversion of VAT to the higher rate and bad weather, both in January, dampened spending in that quarter. Therefore, stronger growth in quarter two partly reflects a comparison with a weaker first quarter.

The same argument applies to net trade, where export volumes were markedly down in the first month of the year - possibly a consequence of the heavy snowfall disrupting the movement of goods to ports. Imports were less affected, obviously relying less on UK land transport. The contribution of net trade to GDP growth, having been negative in 2009 Q4 and 2010 Q1, was negligible in 2010 Q2. This is despite the substantial depreciation in sterling in the second half of 2008 which does not appear to have had much effect in supporting net trade - although it is of course difficult to disprove the counterfactual that the trade contribution to GDP may have been even worse had it not been for the effect of sterling depreciation.

Fixed investment (GFCF) spending declined by 2.4 per cent on the quarter, following a big increase in the previous quarter, and government consumption spending growth fell to 0.3 per cent from 1.5 per cent previously. As yet the data do not support a sustained pick up in fixed investment spending.

The largest expenditure contribution to quarter two GDP growth resulted from 'other' spending. This includes the consumption spending by nonprofit institutions and also spending by businesses on valuables, but both of these are fairly small parts of the level of GDP ( 2.5 per cent and 0.1 per cent respectively) and tend to make minor contributions to quarterly growth. Inventories, or stockholdings represent the works in progress or stocks of intermediate and final goods held by businesses to meet expected future demand. These too are a negligible part in the level of GDP (usually below 1 per cent, 0.3 per cent in 2010 Q2), but can be very significant in explaining changes in the level of GDP. In recent quarters, the change in inventories has been making a positive contribution to growth as the rate at which firms were running down stocks decelerated. In quarter two, stockbuilding actually increased for the first time since the third quarter of 2008, making an even greater positive contribution to growth (Figure 6).

Figure 7 shows the change in inventories as a proportion of GDP and the contributions of changes in stockholdings to GDP in recent years. The fact that both fit on the same axes makes clear that inventories punch above their weight in determining GDP movements. Figure 7 shows that changes in inventories can be volatile in terms of the contribution to GDP growth, but because these movements tend to cancel each other out the effect on GDP over a longer period of time is slight. However, as the economy entered recession in the second half of 2008 a sustained fall in stockbuilding saw inventories fall as a proportion of GDP. In the last three quarters, inventories as a proportion of GDP have risen as the rate of destocking eased before restocking in quarter two was observed.

Cyclical movements in inventories, known as the stocks cycle, tend to amplify cyclical movements in output (GDP), especially in the production industries where stockbuilding is more important. In the downswing orders are increasing 


\section{Figure 7 \\ Change in inventories as a proportion of GDP and contribution to changes in GDP}

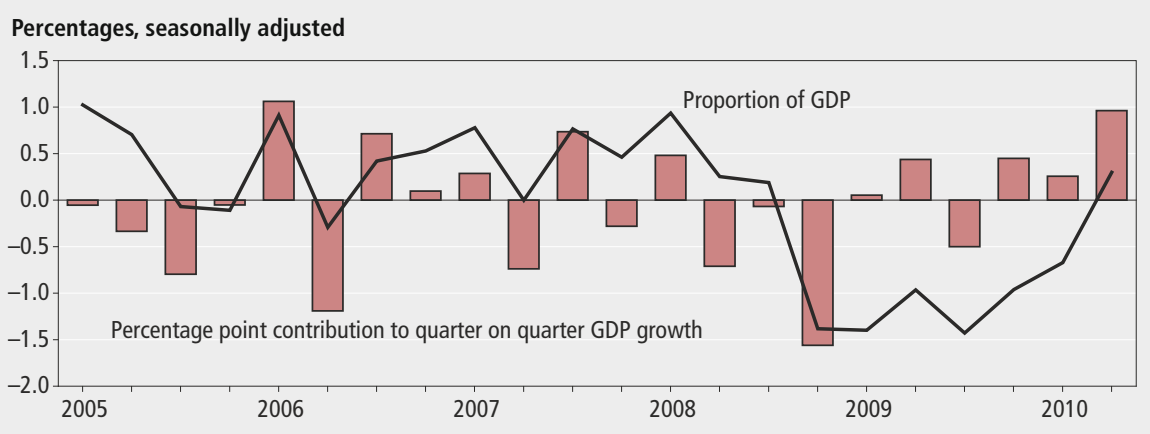

Source: GDP, Output, Income and Expenditure

\section{Figure 8}

\section{Growth in retail sales and household consumption}

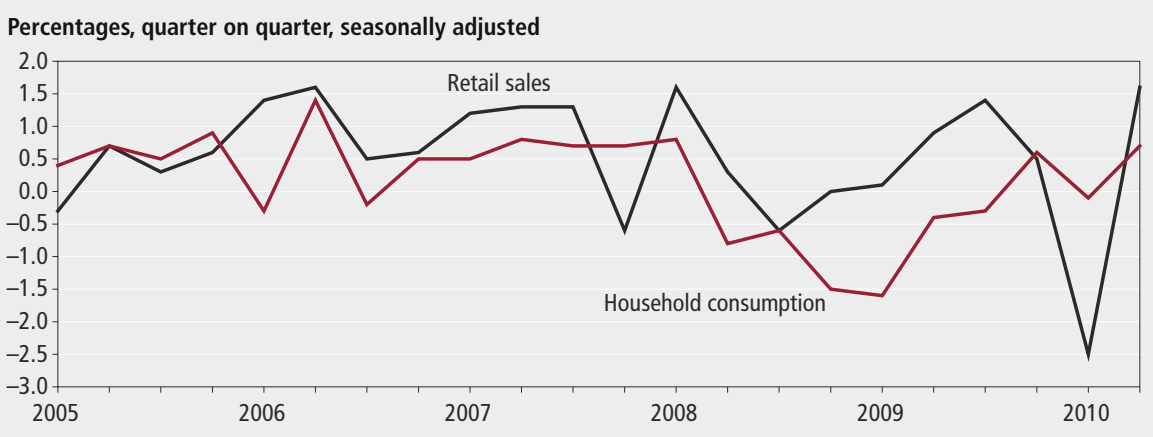

Source: Retail sales and GDP Output, Income and Expenditure

\section{Figure 9}

\section{Contributions to retail sales growth}

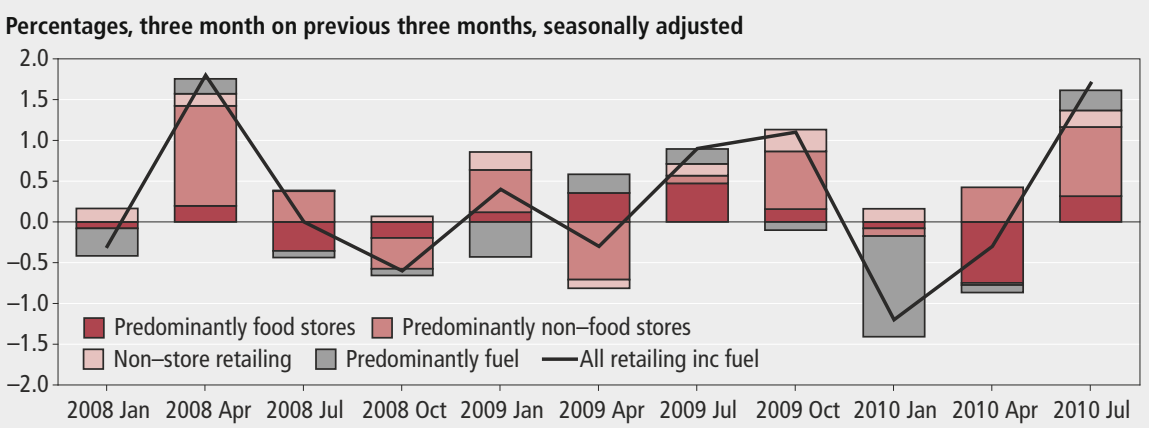

Source: Retail Sales

met from stocks, so output falls often abruptly. In the upswing, output rises faster to not only meet growing demand but to replenish stocks. Therefore, the recent contributions of changes in inventories to GDP are consistent with the observed pick up in production (manufacturing) output.

More detail on the expenditure components of GDP are made available in the Quarterly National Accounts, published next month, and which will give the third estimate of GDP for 2010 Q2. However, ONS has recently published statistics on retail sales, business investment and UK demand-side activity in the UK.

\section{Strong retail sales growth in the three months to July 2010}

\footnotetext{
- igure 8 shows recent trends in retail

- sales and household consumption.

The two time series generally show a good positive correlation, although there are periods of differences. This is not unexpected. Retail sales only represent a proportion of total household consumption - specifically goods bought from retail
}

Trade which all provide views of current establishments. Retail sales will also pick up spending by businesses from retail outlets.

There are two interesting observations from Figure 8. First, retail sales growth, despite slowing down in the recession, was more robust than household consumption as a whole. This suggests that spending on non-retail items, such as motor vehicles and a broad range of services, fell more sharply in the recession than spending on retail goods. Second, retail sales contracted sharply in the first quarter of the year before bouncing back strongly in the second quarter, whereas household consumption has been less volatile.

Figure 9 shows the contributions to retail sales using the most up to date published data - that is up until July 2010 . Spending in predominantly food stores and in non-stores was fairly robust over the recession period. It is not a surprise that retail spending in food stores held up fairly well, being a less discretionary component of spending than most items of consumption. In fact, there may have even been some substitution towards predominantly food stores from hotels and restaurants, and predominantly nonfood stores for items such as clothing and general household goods.

The upward trend in non-store retailing has been driven by a sustained increase in Internet spending (see Figure 10). Internet sales, despite exhibiting a slowdown through the recession, have generally grown faster than retail spending as a whole. As a result the share in total retail spending has risen from 3.0 per cent in January 2007 to 8.0 per cent in July 2010 .

ONS has recently published the Internet Access 2010 statistical bulletin which confirms the strong rise in household and individual Internet usage over the last four years - consistent with the sustained rise in retail sales over the Internet. For example, the percentage of adults accessing the Internet everyday has risen from 35 per cent (16.5 million) in 2006 to 60 per cent (30.1 million) in 2010. The flipside of this is that the percentage of adults who have never used the Internet fell over the same period to 18 per cent (9.2 million) from 35 per cent (16.7 million). Adults who purchased over the Internet in the last 12 months rose from 57 per cent in 2008 to 64 per cent in 2010 - with clothes, sports goods, films, music, household goods and books and magazines among the most popular items, along with non-retail services such as holiday accommodation, travel arrangements and tickets for events.

Retail spending in predominantly 


\section{Figure 10}

Internet retail sales as a proportion of all retail sales

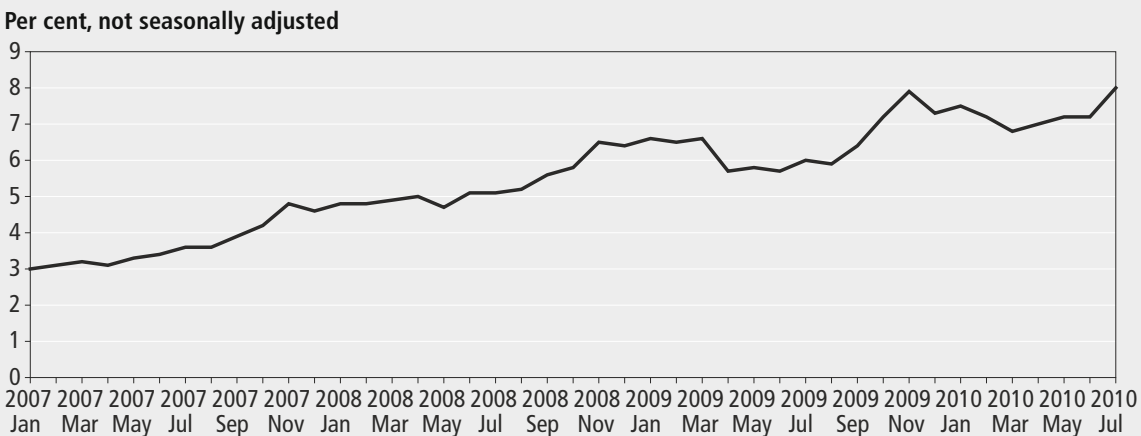

Source: Retail Sales

\section{Figure 11}

\section{Gross fixed capital formation, business investment and contributions to business investment by sector}

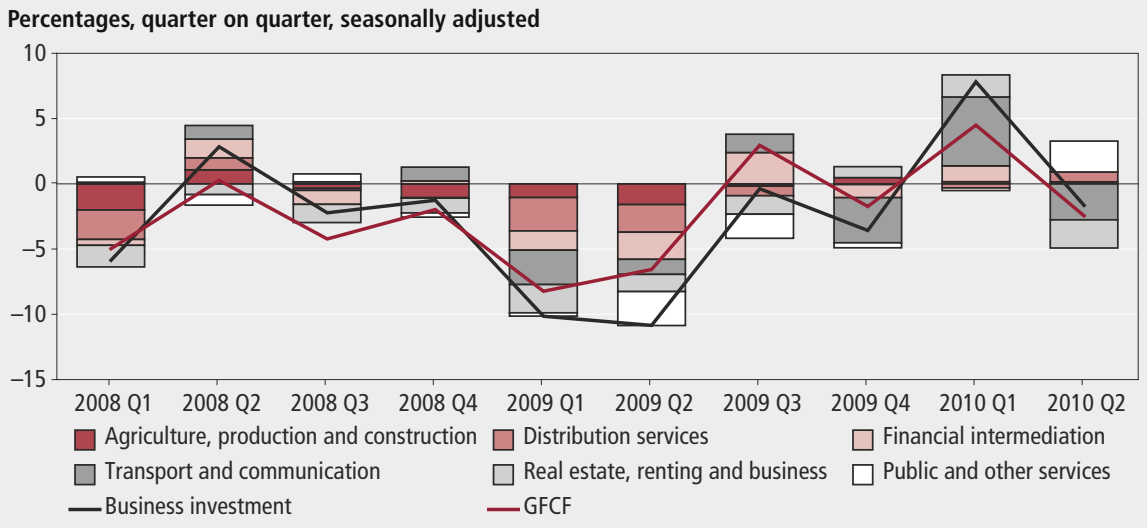

Source: GDP Output Income and Expenditure and Business Investmen

automotive fuel establishments has only recently been classified to the retail sector (February 2010). Its impact has been to add some extra volatility in three-month on three-month sales growth, but for the most part there has not been a sustained effect in either direction on total sales. In the three months to January 2010, retail spending in predominantly automotive fuel fell by 13.5 per cent and reduced total retail sales growth by 1.2 percentage points. This included a 12.3 per cent fall in the month of January alone as heavy snow significantly reduced road transport and disrupted tanker deliveries of fuel to filling stations.

Retail spending in predominantly nonfood stores slowed during the recession, but not by as much as widely expected or by household consumption as a whole. This is despite consisting of more discretionary items of spending at a time when consumer credit has been restricted, the labour market weakened and consumer confidence remains fragile. Here, volumes may have been supported by discounting, especially in the clothing and footwear category of spending.

In the three months to July 2010 , retail sales volumes were 1.7 per cent higher than in the previous three-month period. This was due to a broad-based increase in spending across all the retail spending sub-categories, and particularly in the predominantly non-food stores sector.

\section{Business investment down in the second quarter}

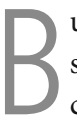
usiness investment accounts for a significant part of total gross fixed capital formation, of which the other main components are dwellings, transfer costs of fixed assets (such as land) and public sector investment. Figure 11 shows the relationship between growth in business investment and total GFCF, and also the contributions to business investment growth by major type of industry. Business investment and total GFCF have generally moved in the same direction, and for the most part, the contributions by industries have been in the same direction.

Quarter on quarter movements in investment spending tend to be volatile, making it more difficult to discern the trend in recent data. However, as yet there does not appear to be a sustained pick up in business investment spending as the UK economy exits from recession. Business investment in 2010 Q2 was still 23.7 per cent below its pre-recession peak in 2007 Q4, and the cumulative fall has been large relative to previous recessions.

Weak investment is likely to reflect significant business uncertainty regarding the future economic outlook. The Bank of England's regional agents recently reported that investment remains focussed on improving efficiency, reducing costs and replacing assets rather than expanding capacity. Business survey data, such as surveys administered by the Confederation of Business Industry (CBI), point to the demand outlook and current spare capacity as being the main factors behind depressed investment intentions.

The availability of finance has therefore been a secondary constraint on investment spending. Although the cost and availability of external finance is more limited than in the years before the financial crisis, business survey respondents had cited an improvement since 2009. This constraint though may become more significant if the economy continues to recover and investment intentions rise.

Internal sources of finance have risen in recent years due to private non-financial corporations (PNFCs) running financial surpluses. These actually grew during the recession as stockbuilding and fixed investment spending fell faster than corporate disposable income (where falling operating profits and property income were also offset by lower tax and dividend payments). Firms may be building cash balances to act as a buffer against future shocks, such as to cover deficits in pension funds that have widened as bond yields and equity prices fell over the course of the downturn. It may also be the case that these cash balances, to some extent, arose automatically as the result of the decision to cut back on investment spending in line with more pessimistic views of future demand.

\section{Exports of goods rebound in the second quarter of $\mathbf{2 0 1 0}$}

n 2010 Q2 net trade was broadly neutral in terms of its contribution to quarterly GDP growth, but this followed three successive quarters where the impact 


\section{Figure 12a \\ Exports and imports and the contribution of net-trade to GDP growth}

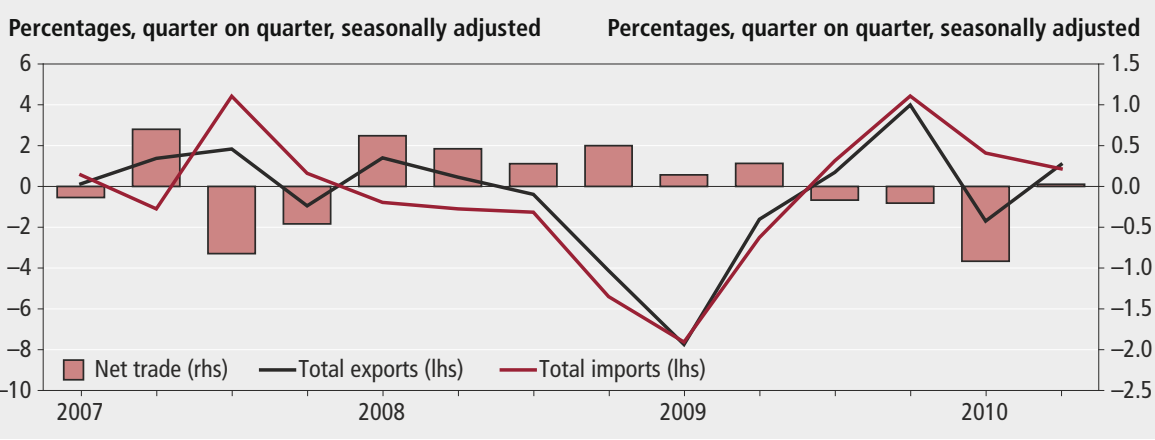

Source: GDP Output Income and Expenditure and UK Trade

\section{Figure $12 b$}

\section{Exports and imports goods inflation and the terms of trade}

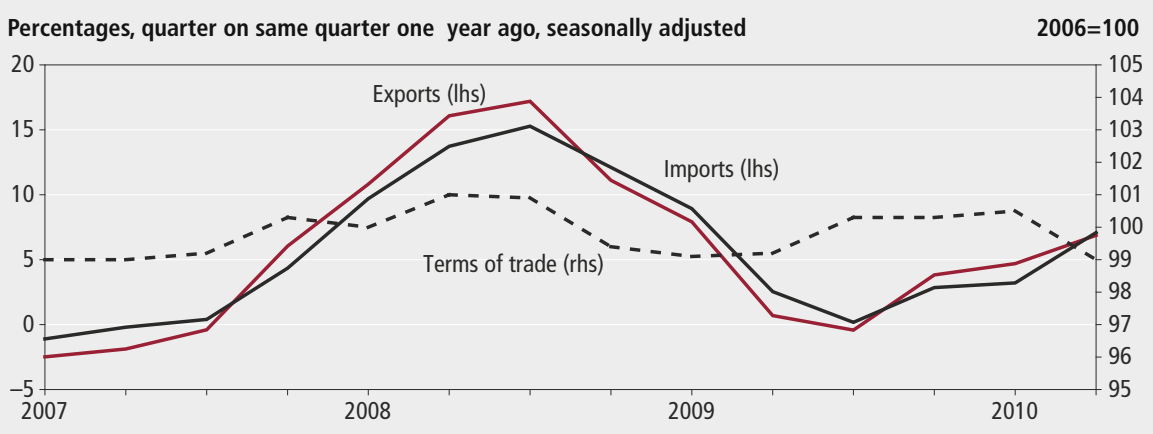

Source: UK Trade

was negative (Figure 12a). As the global economy has shown signs of recovery, UK imports have grown faster than UK exports. The effective sterling exchange rate has depreciated by around 25 per cent since the middle of 2008, yet this does not appear to have provided the boost to net trade that was anticipated, especially by those who have advocated a rebalancing of the economy away from domestic (consumption) to foreign (exports) demand.

This tends to suggest that demand effects have typically outweighed price or competitiveness effects in UK trade. UK imports may have been driven in the last year by the vehicle scrappage scheme and by the deceleration in the rate at which firms were destocking - leading to an increase in imports of vehicles and intermediate goods.

Figure $\mathbf{1 2 b}$ presents UK export and import goods prices inflation, and also the terms of trade which is basically the ratio of export to import prices. These figures are taken from UK Trade statistical bulletin. It is not shown in Figure 12a, but recent trends in UK total imports and exports growth have been driven by trade in goods, which make up the major part of trade, as opposed to trade in services. Figure 12a shows that UK exports and imports goods price inflation have generally moved in line with each other, and therefore there has been little effect on the UK terms of trade. One of the expected consequences of sterling depreciation would be that import price inflation exceeds that of exports, and the terms of trade fall to reflect an improvement in relative competitiveness.

After sterling exited from the European Exchange Rate Mechanism in 1992 its value also depreciated by around a quarter. This was reflected more strongly in the UK terms of trade, which fell by around four index points between 1993 and 1995 . Net trade made a positive contribution to growth in these years as exports picked up strongly.

Exchange rate depreciation though is only expected to provide a fillip to net trade if imports and exports are relatively price elastic - that is demand is sensitive to price. It could be argued that UK exports are no longer as price sensitive as they were almost two decades ago. For example, the structure of UK trade has changed to higher quality goods such as pharmaceuticals and aerospace where quality is likely to be as important as price. As a result, and if UK exports are less price sensitive, exporters may have taken the opportunity to use sterling depreciation to increase margins instead of competitiveness. It may also be the case that foreign exporters to the UK have absorbed some of the effects of sterling depreciation into their own margins to remain competitive in the UK market. These types of pricing to market activities act to offset the impact of exchange rate movements on the terms of trade.

\section{Larger falls in the employment rates of younger people since 2008 Q1}

$\mathrm{n}$ the second quarter of the year (April to June 2010) the headline level of employment (all those aged 16 and over) rose by 184,000 to 29.02 million. The headline employment rate, relating to those aged 16 to 64 , increased from 70.3 per cent in the first quarter to 70.5 per cent. However, as Figure 13a shows, employment rates remain considerably lower than before the recession. In 2008 Q1, the headline employment rate (1664) was 2.5 percentage points higher at 73.0 per cent. Furthermore, there appears to be a distinct age profile in the change in employment rates between 2008 Q1 and 2010 Q2, with the larger falls concentrated in the younger age groups. This is also shown in Figure 13b. Here, the employment rates of the 25-34 and 35-49 have generally followed the same pattern. However, a comparison of the employment rates of the 18-24 and 50-64 age categories shows a marked reduction in the former and little change in the latter.

Younger generations in the workforce are more likely to be adversely affected by a slowdown in recruitment. Having fewer years of experience and years of service may also make redundancy relatively cheaper. This is even more the case now that pension fund deficits and new accountancy standards for the reporting of funded pension positions in company accounts makes early retirement as a means for trimming the labour force perhaps less attractive than in previous downturns. The economic consequences of falling employment in the younger generations are a concern - especially if a prolonged spell of unemployment at a young age causes scarring that harms younger people's longer-term prospects in the labour market. 
Figure 13a

Total change in employment rates by age, 2008 Q1 to 2010 Q2

Percentages, seasonally adjusted

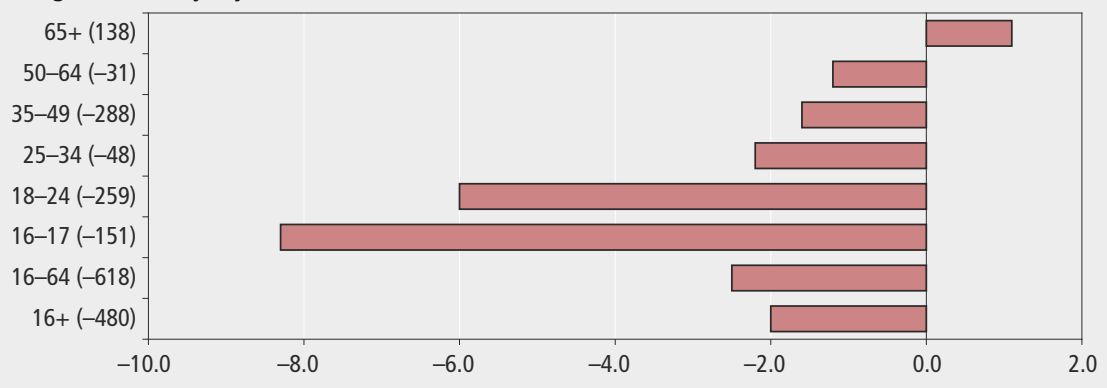

Notes:

Source: Labour Market Statistics

1 Changes in employment (thousands) are in brackets

Figure $13 b$

\section{Trends in employment rates by age}

Percentages, seasonally adjusted

Percentages, seasonally adjusted

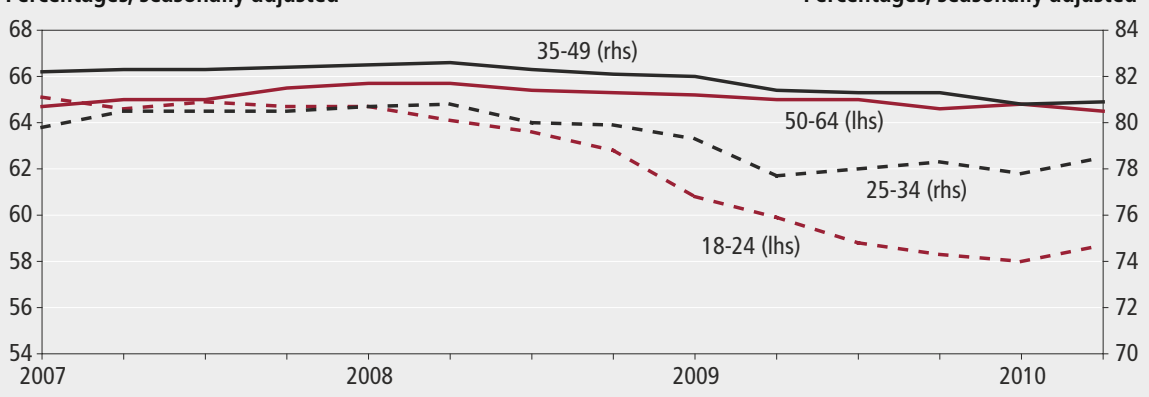

Source: Labour Market Statistics

\section{Figure $14 a$}

Change in total employment, employees and self employment

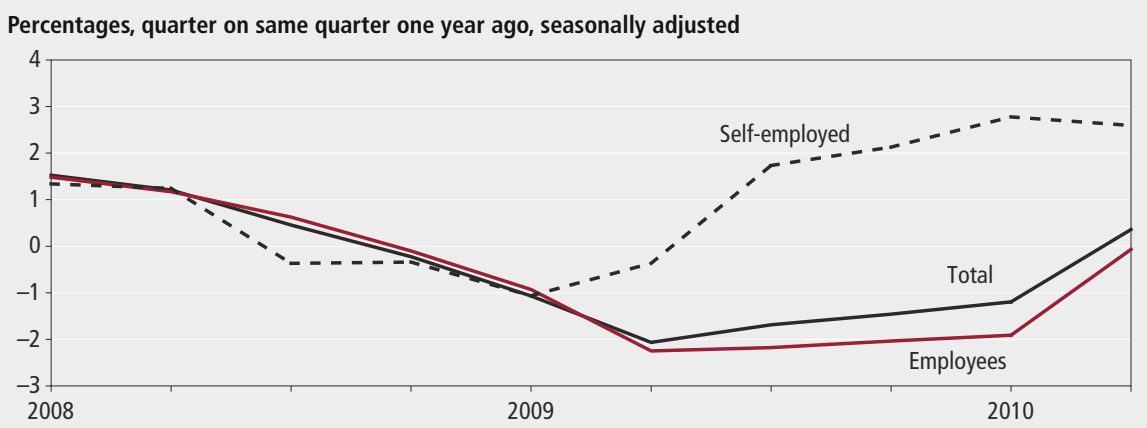

Source: Labour Market Statistics

\section{Figure $14 b$}

\section{Contributions to the change in total employment}

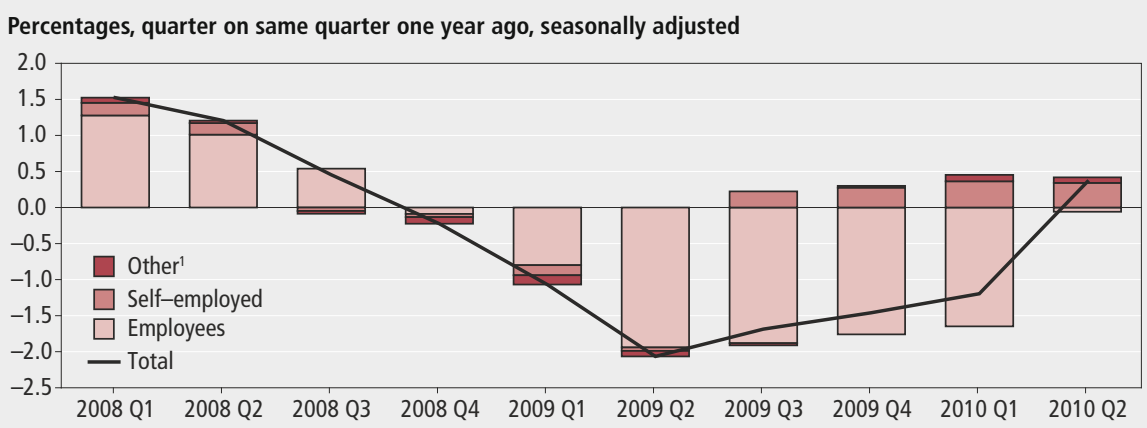

Notes:

Source: Labour Market Statistics

1 Other includes unpaid family workers, government supported training and employment programmes
Self-employment and part-time employment rises

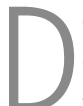
espite the general fall in employment levels and rates through the recession there have been increases in both self-employment levels and part-time employment levels. Figure 14a presents four-quarter growth rates of total employment, employees and self-employment. Figure 14b then shows the contributions to total employment growth since 2008 Q1.

Clearly, self employment picked up significantly through 2009. However, as the self-employed have typically only accounted for between 10-15 per cent of total employment, the contribution to total employment growth is smaller.

This rise in self-employment probably reflects the more limited employee opportunities. Small businesses are normally more capital constrained than larger firms with more collateral, so in some sense, it is surprising that selfemployment has risen so quickly at a time when lending to small businesses has been constrained and the outlook for the housing market, which is often a source of collateral for self-employed people, has been increasingly uncertain. On the other hand, low mortgage rates following aggressive cuts in interest rates, may have created some financial freedom in which to start new businesses. It is also noticeable that a high proportion of the increase in self-employed people are women, so it may be the case that a partner in employment can provide some financial security to the household.

Part-time employment has also risen markedly through the recession (Figure 15a), and although this has been insufficient to offset fully the fall in full-time employment (Figure 15b), it has nonetheless meant that the fall in total employment through the recession was less than it might have otherwise been. The rise in part-time working could be considered an indicator of labour flexibility, where the labour market adjustment to falling demand results in lower hours rather than lower employment. Figure 15c decomposes the four-quarter growth in part-time employment by reason for working parttime, and clearly shows that the main driving factor has been the inability to find full-time work. This therefore points to a rise in underemployment, where workers are constrained to working fewer hours at 
their existing wage rate than they would otherwise wish. Although this reduces the impact of the recession on total employment, growing underemployment still has similar, if less severe, implications for household income and labour market attachment.

\section{Male employment falls faster than female employment through the recession}

$\checkmark$ ot only has the fall in employment had a differential impact on people of different ages, it has also, so far, been more severe for men than women. As Figure 16a and Figure 16b show, the male contribution to the fall in total employment has been much greater. This largely reflects the differential impact of the recession on the industries where men and women work. In the manufacturing and construction sectors the concentration of male employment is substantially higher than female, particularly in construction where women account for a very low proportion of jobs. These industries experienced a much larger fall in output during the recession than the services sector as a whole - with the pass through into employment then affecting men more than women.

In contrast, women are more represented than men in the public services, most notably education and health. These services tend to be insulated from cyclical movements in the economy, in fact employment in the health service has actually increased since 2008 rather than fallen. Therefore female jobs tend to be more secure on average than male jobs, although female employment may therefore be more adversely affected by cuts to the public sector. For completeness it should be mentioned that in the services where the share of men and women are fairly equal, such as business services and finance, the fall in jobs between the sexes has been fairly similar.

\section{Adjustment in hours lowers the impact of the recession on employment}

\footnotetext{
- he rise in part-time working has reduced the impact of the recession on employment by transferring some of the effect of falling labour demand away from the number of people towards the
}

\section{Figure 15a}

Change in total, full-time and part-time employment

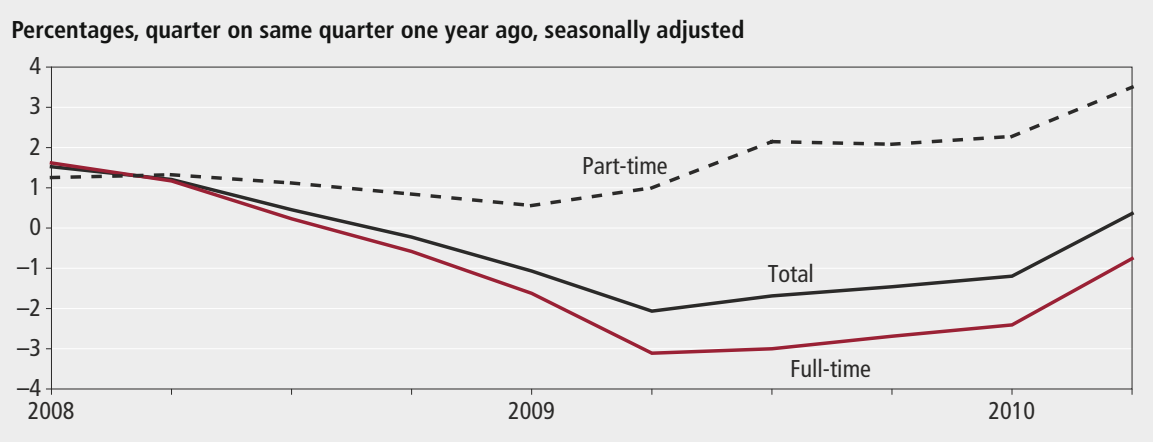

Source: Labour Market Statistics

\section{Figure 15b}

Contributions to the change in total employment by full-time, part-time employment

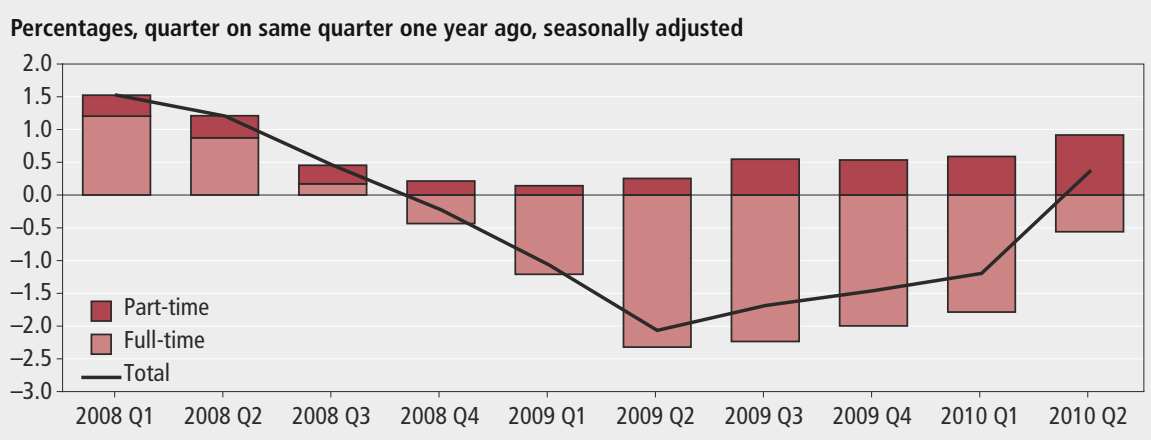

Source: Labour Market Statistics

\section{Figure 15c}

\section{Change in part-time employment by reason for working part-time}

Percentages, quarter on same quarter one year ago, seasonally adjusted

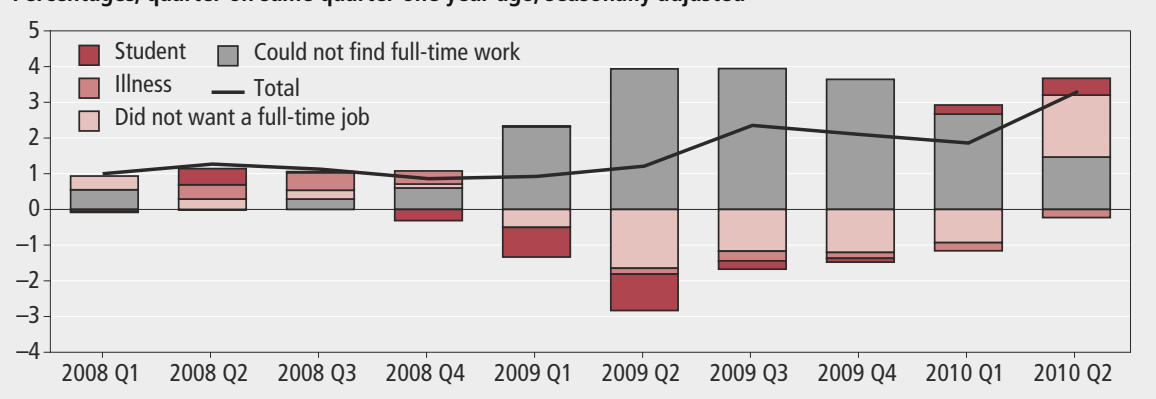

Notes:

Source: Labour Market Statistics

1 Total includes those who did not give a reason for working part-time so total growth rates may differ from Figures $15 a$ and $15 b$

number of hours. Figure 17 breaks down the change in total hours each quarter into two parts: the change in the number of workers and the change in average actual hours worked.

Average actual weekly hours have drifted downwards from 32.2 hours in 2008 Q1 to 31.7 hours in $2010 \mathrm{Q} 2$. Although this works out at around half an hour for each person in employment, when there are around 29 million people in employment this represents a total fall in hours of around 14.5 million - or the equivalent of about 450,000 people working 32.2 hours per week. This rough calculation highlights the importance of hours adjustment alongside employment adjustment in analysing the impact of the recession on the labour market.

As Figure 17 highlights, in some quarters the contribution of falling average hours has been more important than the employment contribution. For example, in 2009 Q1, a number of prominent car producers cut over time and extended the annual Christmas shut down by weeks in some cases and by months in others. The fall in average hours therefore is unlikely 


\section{Figure $16 a$}

Change in total employment, male and female employment

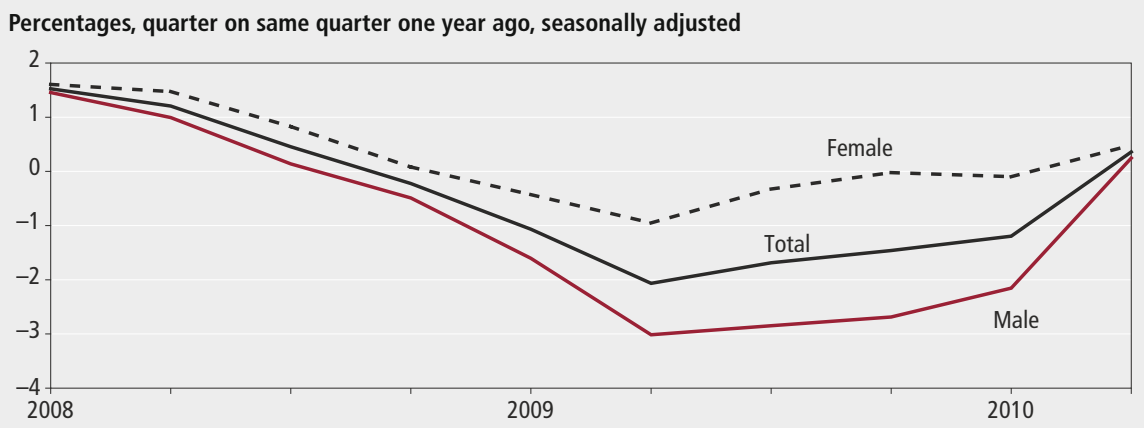

Source: Labour Market Statistics

Figure 16b

\section{Contributions to the change in total employment, male and female employment}

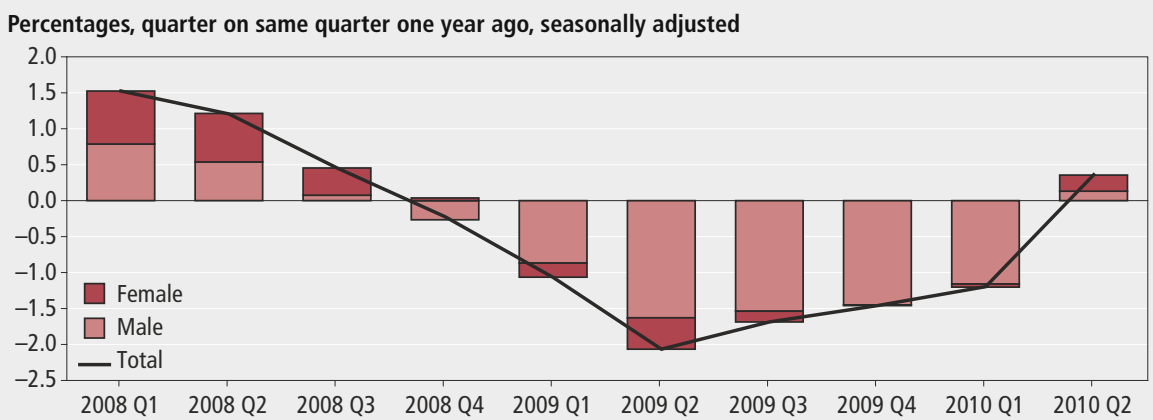

Source: Labour Market Statistics

Figure 17

\section{Change in total hours}

Hours (millions), quarter on quarter, seasonally adjusted

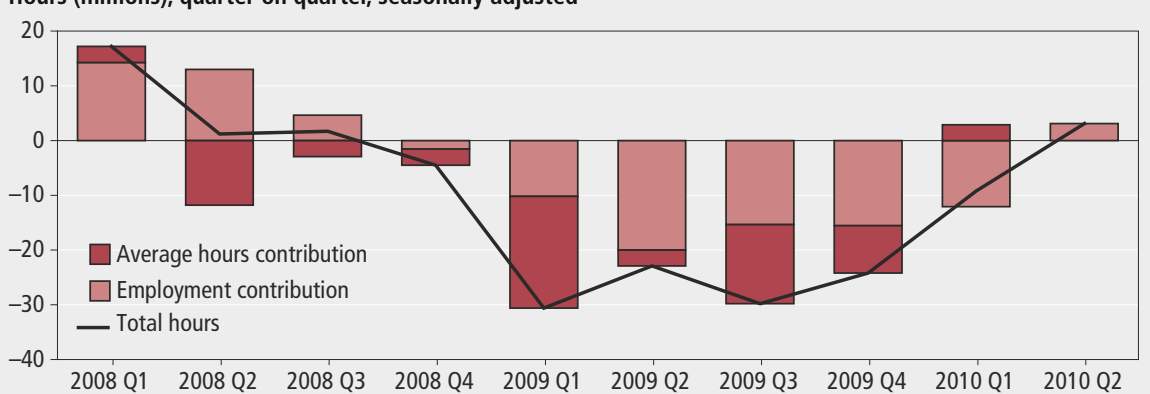

Source: Labour Market Statistics

\section{Figure 18}

\section{Productivity and unit wage costs}

Percentages, quarter on same quarter one year ago, seasonally adjusted

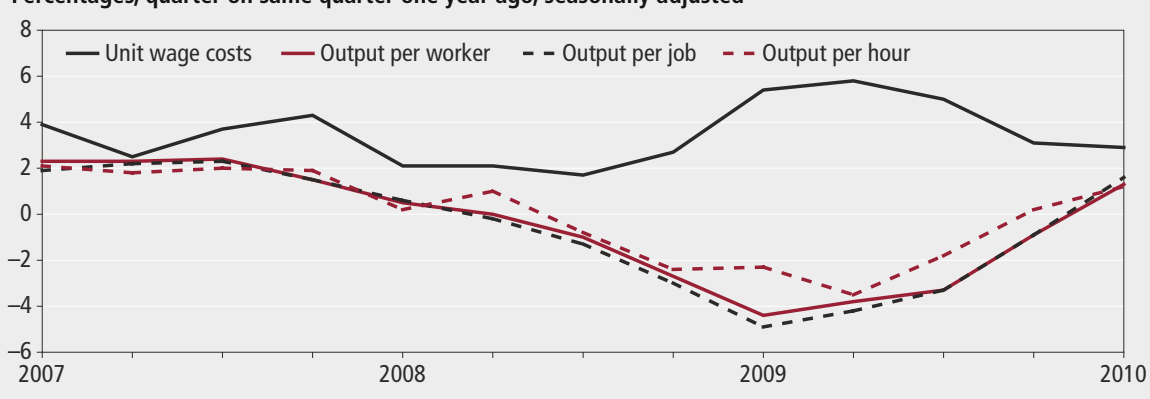

Source: Labour Market Statistics to have been very evenly spread over the entire workforce. So on the one hand it again emphasises the value of preserving employment by reducing hours, but also points to a rise in underemployment and associated problems with that.

\section{Labour productivity begins to improve as output recovers}

$\mathrm{t}$ is widely accepted that firms face costs in adjusting the size of their workforce.

Hiring new labour requires search costs and then training costs, firing labour requires at least statutory redundancy payments. Consequently, labour hoarding may be a rational response to a fall in demand if there is uncertainty over the future path of demand and that it may be costly to rehire and retrain staff when business conditions improve. Firms may therefore find it optimal to vary labour inputs through hours (for example the use of overtime or shorter working periods).

This has been reflected in various measures of labour productivity (see Figure 18). Output per worker and output per job fell to a greater extent than output per hour - reflecting that hours fell by more than jobs and workers in the downturn. Recently, labour productivity on all measures has started to improve as the economy recovers and output (GDP) begins to grow. In this case, and as expected, output per worker and output per job have grown faster than the output per hour measure - suggesting that with spare capacity available and underutilised labour businesses have been able to increase output by raising the productivity of the workers they retained through the recession. However, the logical repercussion of being able to produce more output through higher labour intensity is that employment need not rise immediately in line with GDP if increasing output can be achieved through higher labour productivity.

\section{Producer price inflation continued to reflect movements in oil prices and import prices}

n July 2010, the annual rate of producer prices output inflation, often referred to as factory gate prices inflation, was 5.0 per cent. This compares with 5.7 per cent three months earlier in April 2010, and -1.3 per cent a year earlier in July 2009 
Figure 19a

\section{Producer prices inflation: outputs}

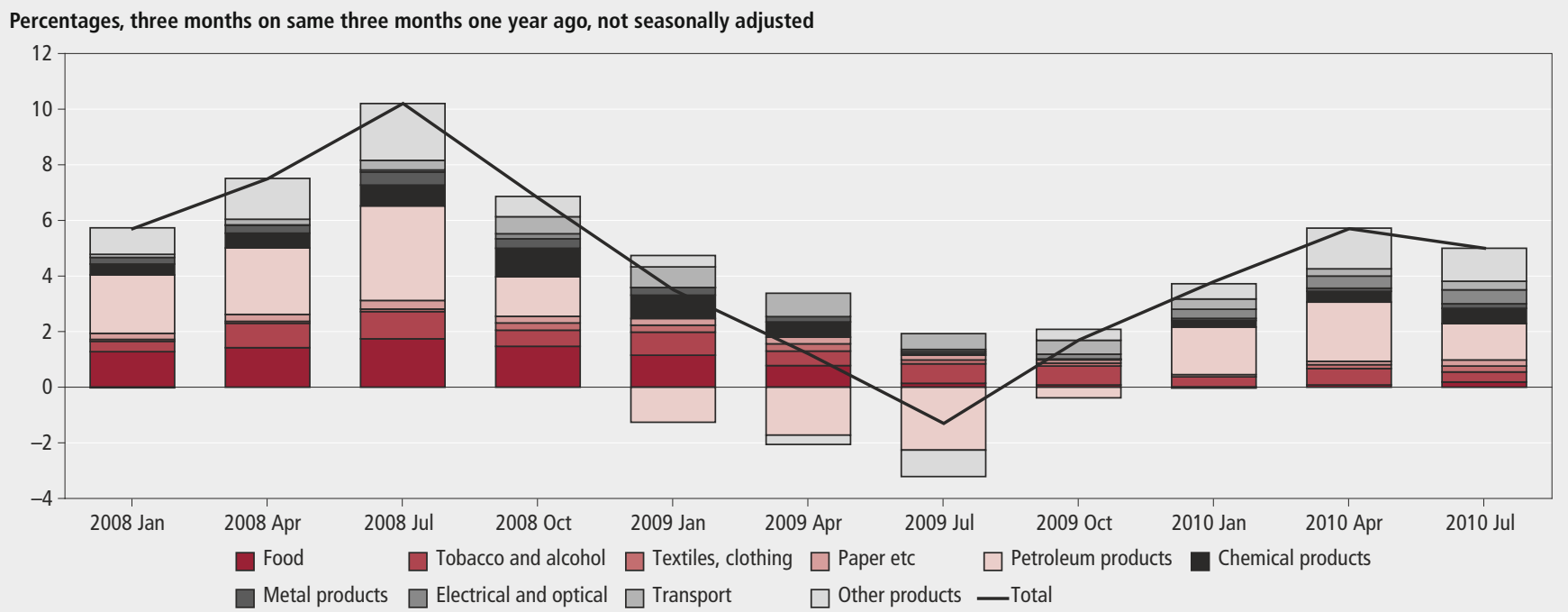

Source: Producer Prices

Figure 19b

Producer prices inflation: inputs

Percentages, three months on same three months one year ago, not seasonally adjusted

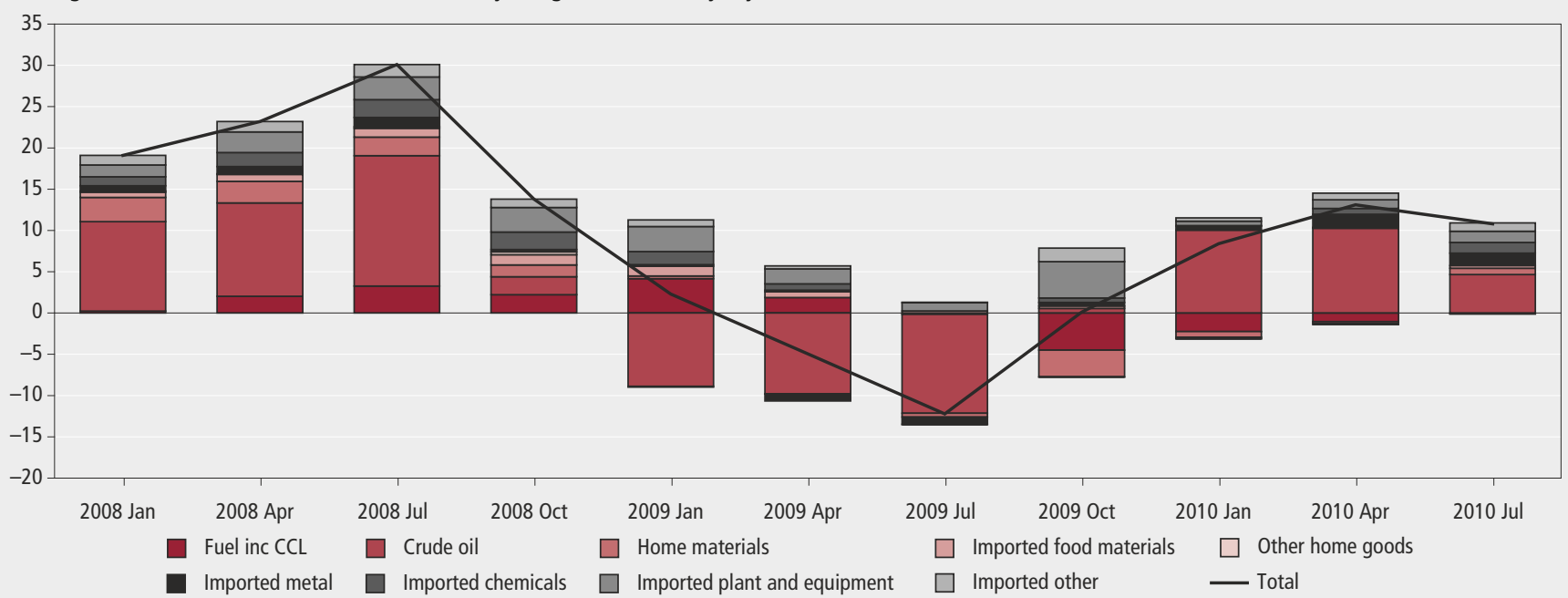

Source: Producer Prices

Figure 20

Services producer prices inflation

Percentages, quarter on same quarter one year ago, not seasonally adjusted

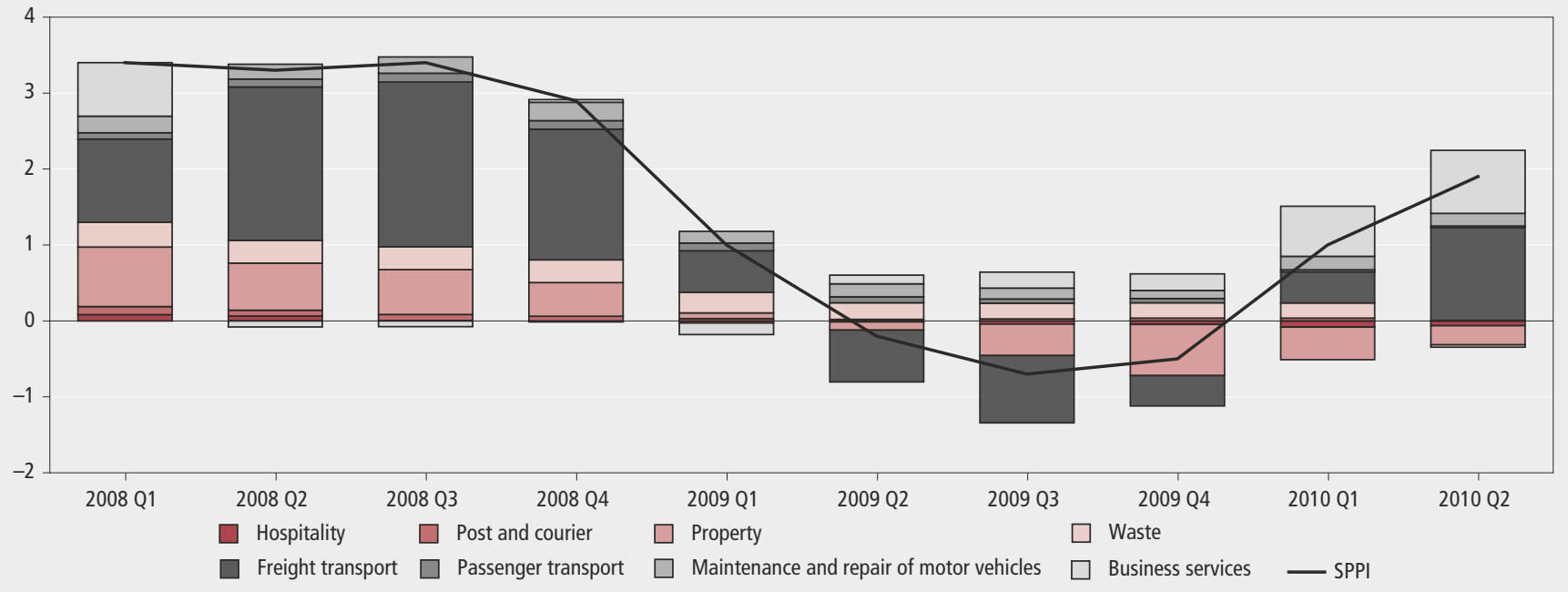

Source: Services Producer Prices 
(Figure 19a). Producer prices inflation over the last year has tended to follow the path of oil prices. In July 2009 the oil price was $\$ 65.8$ per barrel, prices then increased to a peak of $\$ 85.8$ per barrel in April 2010 . Since then the price has moderated a little, falling to $\$ 75.4$ per barrel in July 2010 .

The effect of oil prices on factory gate inflation is most easily observed in the direct impact on petroleum products, which as shown in Figure 19a, has had an important influence on movements in the overall producer price index (PPI).

However, as Figure 19b shows, oil prices have had a significant impact on input price inflation - which then feeds through to output price inflation in a much broader range of commodities. In July 2009 the annual rate of PPI input inflation was -12.2 per cent, rising to 13.1 per cent in April 2010 before falling back to 10.8 per cent in July 2010. Crude oil has been an important driver of these movements. The oil price will also have had an indirect effect on input prices through fuels, chemicals (as a major source of hydrocarbons) and food materials (via the impact of oil prices on bio fuels and hence grain prices)

Figure $19 \mathrm{~b}$ also shows the importance of imported goods as a source of PPI inflation. Although the price of imported materials will largely reflect global commodity prices, movements in the sterling exchange rate can also be important. Depreciation of sterling since the second half of 2008 would be expected to put upward pressure on import prices.

\section{Services Producer Prices Index (SPPI) inflation increases to 1.9 per cent in 2010 Q2}

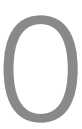

il and other commodity prices also appear to have had an impact on SPPI inflation rates, albeit smaller than on PPI inflation rates. As Figure 20 shows, freight forwarding has been an important recent determinant of annual SPPI inflation, and this is likely to be influenced by fuel costs. However, other components of the SPPI have tended to follow a cyclical pattern and have been less influenced by global commodity prices. Property is the most notably example, making a negative contribution to annual SPPI inflation through the recession as commercial rents fell as supply outstripped demand. The recent pick up in SPPI inflation, from - 0.5 per cent in 2009 Q4 to 1.9 per cent in $2010 \mathrm{Q} 2$, has also been driven by business services where margins and staff costs may have started to rise in line with the recovery in output and business confidence.

\section{CONTACT}

C elmr@ons.gov.uk 